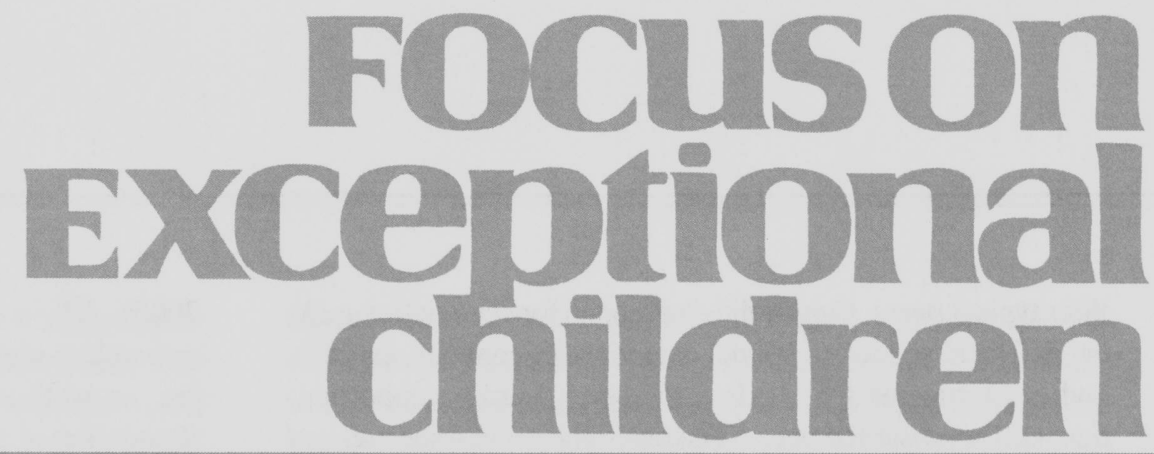

\title{
Best Practices and Considerations: Including Young Children with Disabilities in Early Childhood Settings
}

\section{Lee Cross, Marisa J. Salazar, Natalie Dopson-Campuzano, and Heather W. Batchelder}

Since 1975, federal law has required that children with disabilities have access to a free appropriate education (FAPE) in the least restrictive environment (LRE). Subsequent reauthorizations of this legislation have continued to stress educating children in the LRE, including preschool children with disabilities. Legislation regarding the inclusion of students with exceptionalities is rooted in the premise that all children with disabilities should be educated in naturalistic settings with typically developing peers. The goal of inclusion is to provide all children with equitable access to educational opportunities. Inclusion is not specifically defined in the law but is supported through the mandate of providing services in the least restrictive and natural environments (CONNECT, 2009; IDEA, 2004). The benefits of inclusion for children with disabilities as well as for typical developing children have been documented in the literature (Odom, 2000; Stahmer \& Carter; 2005; Tsao et al., 2008). Even though the evidence on the impact of inclusion in relation to child outcomes is somewhat limited, the rationale for inclusion can be approached from three main perspectives: philosophical, legal, and educational (Bailey, McWilliam, Buysse, \& Wesley, 1998).

In April 2009, both the National Association for the Education of Young Children (NAEYC) and the Division of Early Childhood (DEC) of the Council for Exceptional Children (CEC) approved a joint position statement on early childhood inclusion. The joint position paper affirmed:

\begin{abstract}
Early childhood inclusion embodies the values, policies and practices that support the right of every infant and young child and his or her family, regardless of ability, to participate in a broad range of activities and contexts as full member of families, communities and society. The desired results of inclusive experiences for children with and without disabilities and their families include a sense of belonging and membership, positive social relationships and friendships, and development and learning to reach their full potential. (DEC/NAEYC, 2009, p. 2)
\end{abstract}

According to the U.S. Department of Education (2008), in 2007 a total of 707,848 children aged 3-5 years with disabilities were served under IDEA, Part B. Over 240,000 children were served in early childhood settings with their typical peers more than $80 \%$ of the time, and 154, 957 children age 3-5 were provided special education services in self-contained classes. Thus, it appears that more and more young children are being included with

Lee Cross is an Associate Professor, and Marisa Salazar and Natalie Dopson-Campuzano are doctoral students in the Department of Special Education at the University of Central Florida. Heather Batchelder is an Instructor in Early Childhood Education at the University of Central Florida. 
their typical peers. One of the challenges for state policy makers and local school personnel is to identify contexts, settings, and environments for children to access learning opportunities with nondisabled peers. The challenges and issues related to accessing environments that support inclusion are beyond the scope of this paper. We are operating under the premise that families and stakeholders are identifying mechanisms within states and local communities to expand the opportunities for young children with disabilities to gain access to programs and services with their same-age nondisabled peers.

The DEC/NAEYC joint position paper recognizes that all young children have the right, regardless of ability, to participate in a broad range of activities and contexts in order to reach their full potential (2009). The statement enumerates three features of high quality programs and services for young children with disabilities, which include access, participation, and supports.

The purpose of this paper is to present a discussion of strategies and practices to ensure access, participation, and supports through family-centered and child-focused practices identified by DEC (Sandall, Hemmeter, Smith, \& McLean,

\section{FOcuson Exceptional children}

ISSN 0015-511X FOCUS ON EXCEPTIONAL CHILDREN (USPS 203-360) is published monthly except June, July, and August as a service to teachers, special educators, curriculum specialists, administrators, and those concerned with the special education of exceptional children. This publication is annotated and indexed by the ERIC Clearinghouse on Handicapped and Gifted Children for publication in the monthly Current Index to Journals in Education (CIJE) and the quarterly index, Exceptional Children Education Resources (ECER). The full text of Focus on Exceptional Children is also available in the electronic versions of the Education Index. It is also available in microfilm from Serials Acquisitions, National Archive Publishing Company, P.O. Box 998, Ann Arbor, MI 48106-0998. Subscription rates: individual, \$48 per year; institutions, \$66 per year. Copyright (C) 2009, Love Publishing Company. All rights reserved. Reproduction in whole or part without written permission is prohibited. Printed in the United States of America. Periodical postage is paid at Denver, Colorado. POSTMASTER: Send address changes to:

Love Publishing Company

Executive and Editorial Office P.O. Box 22353

Denver, Colorado 80222

Telephone (303) 221-7333

\section{EDITORIAL BOARD}

Lisa Dieker

University of Central Florida
Paula Maccini

University of Maryland
Marleen Pugach

University of Wisconsin-Milwaukee
2005). These recommended practices are supported by research evidence, experience, and the values of stakeholders, as well as field validation of the identified practices (Sandall et al.). Finally, we will conclude with a discussion of personnel development, which is one of the most critical factors in ensuring effective inclusion.

\section{FAMILY-CENTERED PRACTICES}

Positive school and family collaborative relationships are fundamental for the successful integration of children with and without disabilities within inclusive preschool settings. Effective family-centered practices are described by Sandall et al. (2005) as involving: (a) shared responsibility and collaboration, (b) strengthened family functioning, (c) individualized and flexible practices, and (d) strengths and assets based practices. When applying family-centered practice guidelines, professionals should consider both the overall and the individual needs of the children and families that they serve.

Educators who employ shared responsibility and collaboration strive to establish positive relationships with parents in order to develop mutual goals that support children in achieving their full potential. Through frequent sharing and communication with caregivers, positive relationships are established. As caregivers experience quality interactions, attitudes about inclusion are enhanced (Green \& Stoneman, 1989). However, the key to successful collaboration is consideration of the family's style of understanding and information processing. Educators need to carefully distribute information in a way that matches each family's style.

Early childhood educators can support and strengthen family functioning by providing resources for parents that empower and promote competence. Parent education opportunities along with informal supports from existing community life can foster family functioning. Teachers and schools are in a good position to link families with a variety of community resources and services. Parents, teachers, and schools can work together to make sure that all children have access to the resources available to help foster healthy family development.

Professionals are encouraged to provide resources and supports for families in ways that are flexible, individualized, and personalized in order to meet the needs of each family, taking into consideration the unique family background and situation (Xu, 2007). Reflection and flexibility allows educators to be able to adjust their practices when appropriate in order to accommodate a family's needs. Educators need to be cognizant of the multiple challenges that families of children with disabilities may encounter, such as substantial time demands, psychological stress, increased medical expenses, and caregiving responsibilities that limit flexibility (Turnbull, Turnbull, Erwin, \& Soodak, 2005). Parents want to feel heard, taken seriously about their views of their 
child, and treated as equal partners in the collaboration process (Pruitt, Wandry, \& Hollums, 1998). Educators who use individualized and flexible practices consider both classroom and family needs when developing student goals.

Strengths- and asset-based practices involve using the strengths of the family when developing interventions. Bruder (2000) identified "a blatant disconnect between what the families perceived as learning opportunities for their child in the home and community and what was occurring in the children's formal intervention programs." Families need to be involved as equal partners in identifying appropriate learning opportunities that can be addressed in the home. Educators must consider what families value as well as the strengths or skills they have to offer (Bruder). Rather than approaching problems from a needs perspective, it is critical to identify and reinforce existing family strengths. This approach ascertains what the family does well along with the existing family support systems. As educators enable and empower families, caregivers are more able to meet the needs of the child (Dunst \& Dempsey, 2007).

\section{Considerations for Working with High Needs Families}

Currently, within the nation's preschool inclusive settings, teachers serve children with a variety of needs, including those who are from culturally and linguistically diverse (CLD) backgrounds, living in poverty, or both. According to the National Center for Children in Poverty (2007), nearly 30 million children in the United States come from lowincome homes, and of these children, $73 \%$ come from CLD backgrounds. The National Clearinghouse for English Language Acquisition (2007) confirms an increasing number, estimated at 9.9 million, of multilingual children in the nation's schools (as cited in Ballentyne, Sanderman, D'Emilio, $\&$ McLaughlin 2008). In addition, one out of three families enrolled in Head Start and Early Head Start speak a language other than English at home (Ballentyne et al.). Children from CLD backgrounds who live in low-income homes often face barriers that delay their development. These barriers include a lack of access to quality healthcare and social services, lack of exposure to experiences that promote early literacy, and the challenges of acquiring two languages concurrently (Iruka, 2009; Wall et al., 2005). Additionally, barriers faced by low income and CLD families often translate into significant stressors that overpower ethnic differences in family structural characteristics and parenting practices (Iruka, 2009). Despite the obstacles faced by low-income and CLD children and families, strengths-based support in positive parenting practices within cultural frameworks are related to positive child outcomes.

When working with low-income and CLD families with children with special needs, it is important for educators to build a bridge between the cultures of diverse families and the culture of schools (Maschinot, 2008). Educators need to identify the cultural values embedded within the school's interpretation of a student's difficulties and collaborate with families in order to find effective ways to adapt professional interpretations or recommendations within the value system of the family being served (Harry, Kalyanpur, \& Day, 1999). When these considerations are made, families feel respected and supported in teaming with educators on their child's needs. Educators can further improve this collaborative partnership by empowering parents to increase their ability to problem-solve when encountering difficult life situations related to their child's needs. Thus, caregivers become more informed and are better prepared to make decisions and find resources to overcome obstacles in seeking the most appropriate services for their child's unique needs. In order to incorporate family-centered practices, educators need to identify family stressors, perceptions of life issues, resources, and coping strategies (Xu, 2007, 2008).

Growing evidence indicates that the key to providing the best inclusive environment for children with and without disabilities from CLD backgrounds is to ensure a high-quality preschool where teachers are trained in early childhood, implement developmentally appropriate practices, are knowledgeable in the second language acquisition process, recognize their own cultural biases and school biases, and finally are open and willing to establish nontraditional ways to collaborate with families (Harry et al., 1999; Sandowski, 2006). Educators can expand upon traditional approaches to parent involvement by incorporating home visits, parent discussion groups, parent resource rooms, and home lending libraries. In order to reduce the gap between the home and school environments, teachers are in an ideal position to listen to parents' cultural knowledge and daily routines, establish a mutual partnership, and create developmentally appropriate activities that relate to both the school and home environments. This collaboration acts as a bridge between the home and school to help children feel that learning opportunities occur in both places, which will have positive results throughout the child's life (Ballentyne et al., 2008; NAEYC, 2009).

\section{CHILD-FOCUSED PRACTICES}

Developmentally appropriate programs for preschoolers utilize curricula that emphasize many child-initiated activities that are facilitated and expanded by the classroom teacher. Natural environments are employed to create daily routines that provide structure and security for child-focused activities. Natural environments are defined as settings that are typical for the child's same-age peers without disabilities. However, the natural environment goes beyond the child's physical location. Chai, Zhang, and Bisberg (2006) conceptualize natural environment practices as spanning 
three domains: (1) natural environments or settings; (2) naturalistic specialized instruction; and (3) interactions within daily routines and activities of the family, program, and community. Not only must children with disabilities be included within the same activities as their typically developing peers, they must also be supported within those activities. Child-focused learning opportunities can be embedded within typical centers that are chosen by the child and may include (a) dramatic play, (b) blocks and trucks, (c) reading/language arts, (d) puzzles/manipulatives, (e) art, (f) music, and $(\mathrm{g})$ water/sand play (Grisham-Brown, Hemmeter, \& Pretti-Frontczak, 2005; Hohmann \& Weikart, 2002; Sandall \& Swartz, 2008). Nonetheless, educators continue to report considerable challenges in developing learning activities for students with disabilities (Dinnebeil, McInerney, Fox, \& Juchartz-Pendry, 1998). Educators are seeking additional support in planning activities with accommodations and modifications that are needed both in content and instructional strategies (Filler \& Xu, 2006-2007).

An indicator of program quality and effectiveness is that all children have access to and participate in the curriculum through multiple means of representation, engagement, and expression, which are the principles of Universal Design for Learning (UDL; DEC, 2007). UDL is a paradigm that provides all children with access to learning opportunities at every level. Educators provide multiple means for children to engage with a concept, multiple means of representation, and multiple ways to express knowledge gained through interaction with the concepts (DEC; Rose \& Meyer, 2002; Rose, Meyer, \& Hitchcock, 2005). Teachers can embed learning opportunities within classroom activities using multiple means of representation by offering various learning opportunities and materials at different levels of complexity. Multiple means of engagement are applied when professionals plan activities that appeal to children of different abilities, interests, preferences, and cultural backgrounds as well as at different levels of challenge. Multiple means of expression should provide learners with choices in determining how they will demonstrate and express their knowledge and skills, either verbally or nonverbally.

By considering the range of diversity of learners at the initial planning stages, educators will be able to ensure access to educational experiences for all children regardless of ability. Even with a great deal of thought being given to universal design of the curriculum, staff may find it necessary to develop accommodations and modifications to instruction, curriculum, and participation to assure that all children have access and participate in meaningful activities. DEC (2007) defined accommodations as acts made to level the playing field and provide access and opportunity without altering the activities or curriculum, whereas modifications are substantial changes in the activity and curriculum.
Physical arrangements of the classrooms must be assessed and arranged to promote appropriate access for all children. Successful inclusion also requires important consideration for appropriate materials and equipment. Active collaboration with other service providers such as occupational, speech, and physical therapists can help to identify and create appropriate materials for diverse learners. Gregory (1996) suggests incorporating toys with social components to facilitate peer interactions such as puppets, dress-up clothes, housekeeping materials, and vehicles. Inclusive preschools may also need to make adjustments with regard to increasing staff-to-child ratios. Appropriate ratios will vary based on the number of students with disabilities as well as the level of impairments. Despite the number of staff members, collaboration across disciplines and communication among staff members are vital. In addition to accommodations and staffing needs, Gregory also emphasized three major components of curriculum development: (1) developmentally appropriate practice, (2) activity based approach to intervention, and (3) collaborative team approach.

Developmentally appropriate practice both identifies predictable group patterns common to child development and emphasizes a need for individualization based on children's specific needs and learning styles (Filler \& Xu, 2006-2007). NAEYC defines Developmentally Appropriate Practice across three levels: (a) knowledge of age-related child characteristics that can predict possible activities, materials, interactions, or experiences that will be safe, healthy, interesting, achievable, and challenging to children; (b) knowledge of the strengths, interests, and needs of each individual child within a group to plan for needed accommodations; and (c) knowledge of children's social and cultural contexts to ensure that learning experiences are meaningful, relevant, and respectful to the children and their families (Copple \& Bredekamp, 2009). Thus, Developmentally Appropriate Practice is designed to allow for the inclusion of children with disabilities within natural environments.

Naturalistic interventions that are embedded into classroom routines and activities allow teachers to provide specialized instruction without having to separate from the large group of the classroom (Odom, 2000). Although most naturalistic interventions stem from traditional behavior approaches to interventions, they remain compatible with the common constructivist philosophy shared by early childhood educators. Teachers often require additional support with assessment and the complex planning and implementation process that is associated with routines-based interventions. When using traditional child-focused assessments, the connection between assessment outcomes, functional goals, and intervention that takes place within the context of classroom routines often breaks down. Instead, assessment needs to be conducted in a manner that reflects 
the needs of the child within the context of his or her natural environment.

Designing and embedding meaningful learning opportunities throughout the day requires explicit planning. Various planning models focus on the development of activity matrices, which break down each goal across daily activities and routines (Filler \& Xu, 2006-2007; Grisham-Brown et al., 2005; Noonan \& McCormick, 2006; Sandall \& Schwartz, 2008). When developing an activity matrix to organize and plan for routines-based interventions, one needs to consider instructional emphasis for the target child, activities that provide opportunities to address the needs of the target child, any accommodations and modifications that are needed to provide related services within typical classroom routines, and how the family can address goals within the home or community (Filler \& Xu, 2006-2007). Systematic planning time is required to identify the variety of natural learning opportunities that exist within classroom routines as well as appropriate opportunities for more specialized instruction. The activity matrix also encourages collaboration to support meaningful learning across contexts. When collaborating with families, educators can help parents identify meaningful learning opportunities that occur within home routines. As discussed previously, careful consideration of family learning styles is critical when engaging in collaborative planning and sharing. Targeting learning opportunities across a variety of meaningful contexts maximizes progress relating to child outcomes. See the Appendix for tools in collaborative planning for routines-based instruction across home and school environments.

Engaging children in developmentally appropriate activities throughout the day supports positive behaviors and child success. Developmental and behavioral needs are best addressed when instructional techniques are individualized and applied within meaningful contexts (Dunlap et al., 2006; GrishamBrown, et al., 2005; Janko \& Schwartz, 1997; Noonan \& McCormick, 2006). Early childhood educators can overcome the challenges associated with inclusion by providing embedded learning opportunities within a quality early childhood curriculum that supports child-focused instructional strategies (Odom, 2000; Sandall \& Swartz, 2008).

To ensure high quality inclusion, the joint DEC/NAEYC position statement on inclusion recommends the use of specialized instruction and intervention approaches. Specialized instruction includes both embedded interventions as well as explicit strategies that are more directive and targeted. In recent years tiered instructional approaches have emerged that accommodate the range of learners' needs in the areas of social-emotional development and addressing challenging behaviors (Coleman, Buysse, \& Neitzel, 2006; Dunlap et al., 2006; Fox, Dunlap, Hemmeter, Joseph, \& Strain, 2003; Hemmeter, Ostrosky, \& Fox, 2006; Sandall \& Schwartz,
2008). The idea behind the tiered approach is that the foundation consists of developmentally appropriate curriculum for all children, and then more specialized approaches for children who have the need for additional support and access. Decisions about the level of support move from least to most intense (Buysse \& Hollingsworth, 2009). When teaching young children with varying abilities, child-focused instructional strategies should incorporate careful planning, repetition, and scaffolding, as well as multiple means of engagement, representation, expression opportunities for practice, and strategies to encourage higher order thinking (DEC, 2007; Noonan \& McCormick, 2006; Pretti-Frontczak \& Bricker, 2004; Sandall \& Swartz, 2008).

\section{PROFESSIONAL DEVELOPMENT}

Ultimately, successful inclusion of children with disabilities depends on the quality and effectiveness of the teachers, caregivers, and staff involved (Buysse \& Hollingsworth, 2009; National Professional Development Center on Inclusion, 2009). Effective teachers and childcare providers have a positive effect on the learning and development of all children (Darling-Hammond, 2000; NAEYC, 2009). Professional development programs for general and special educators in early childhood must prepare individuals to work collaboratively with colleagues and families, embrace the philosophy of inclusion, provide research-based strategies for practical use in the classroom, and include field experiences in inclusive environments (Stayton, 2003).

As previously stated, the nation is facing a rapid growth of children and families from diverse cultural and linguistic backgrounds; therefore, it is urgent to ensure that educators and caregivers are provided with high quality preparation in second language acquisition and ways to blend the home and school curriculum. Part of the focus of this professional development needs to involve making providers aware of their own perspectives and biases (Harry et al., 1999; Lim \& Able-Boone, 2005). This process of self-reflection supports effective collaboration and relationship development. Professional development should help teachers identify valuable strategies for involving and empowering families.

Family collaboration acts as a bridge between the home and school to help children feel that learning opportunities occur in both settings (Ballentyne et al., 2008; Maschinot, 2008; NAEYC, 2009). Nonetheless, in the classroom, teachers feel inadequately prepared to provide services to students' with disabilities (Jancko \& Schwartz, 1997). Many preschool educators have little experience with specific disabilities or more severe impairments; thus, educators feel unprepared when working this population (Dinnebeil et al., 1998; Lee, Ostrosky, Bennett, \& Fowler, 2003). By preparing educators to use child-focused practices, including UDL and embedded 
learning opportunities within a developmentally appropriate preschool program and the home, the efficacy of inclusion for all children will be increased (DEC, 2007; Grisham-Brown, et al., 2005; Pretti-Frontczak \& Bricker, 2004; Sandall, \& Schwartz, 2008). Thus, as educators are prepared in quality practices to address the strengths and needs of all children, knowledge of specific disabilities becomes less of a concern.

\section{REFERENCES}

Bailey, D. B., McWilliam, R. A., Buysse, V., \& Wesley, P. W. (1998). Inclusion in the context of competing values in early childhood education. Early Childhood Research Quarterly, 13(1), 27-47.

Ballantyne, K. G., Sanderman, A. R., D’Emilio, T., \& McLaughlin, N. (2008). Dual language learners in the early years: Getting ready to succeed in school. Washington, DC: National Clearinghouse for English Language Acquisition. Retrieved May 15, 2009, from http://www. ncela.gwu.edu/resabout/ecell/earlyyears.pdf

Bruder, M. B. (2000). Family-centered early intervention: Clarifying our values for the new millennium. Topics in Early Childhood Special Education, 20(2) 105-115.

Buysse, V., \& Hollingsworth, H. L. (2009). Program quality and early childhood inclusion: Recommendations for professional development. Topics in Early Childhood Special Education, 29, 119-128.

Chai, A. Y., Zhang, C., \& Bisberg, M. (2006). Rethinking natural environment practice: Implications from examining various interpretations and approaches. Early Childhood Education Journal, 34(4), 203-208.

Coleman, M. R., Buysse, V., \& Neitzel, J. (2006). Recognition and response: An early intervening system for young children at risk for learning disabilities. Executive summary. Chapel Hill: The University of North Carolina, FPG Child Development Institute.

CONNECT: The Center to Mobilize Early Childhood Knowledge. (2009). Policy advisory: The law on inclusive education. Chapel Hill: The University of North Carolina, FPG Child Development Institute, Author. Retrieved May 21, 2009, from http://community. fpg.unc.edu/resources/ articles/CONNECT_PolicyAdvisoryOnInclusion_6-2009.pdf/view

Copple, C., \& Bredekamp, S. (Eds.). (2009). Developmentally appropriate practice in early childhood programs serving children from birth through age 8 (3rd ed.). Washington D.C.: National Association for the Education of Young Children.

Darling-Hammond, L. (2000). Teacher quality and student achievement: A review of state policy evidence. Education Policy Analysis Archives, $8(1), 203-216$.

DEC/NAEYC. (2009). Early childhood inclusion: A joint position statement of the Division for Early Childhood (DEC) and the National Education Association for the Education of Young Children (NAEYC). Chapel Hill: The University of North Carolina, FPG Child Development Institute. Retrieved May 10, 2009, from http://community. fpg.unc.edu/resources/articles/Early_Childhood_Inclusion

Dinnebeil, L., McInerney, W., Fox, C., \& Juchartz-Pendry, K. (1998). An analysis of the perceptions and characteristics of childcare personnel regarding inclusion of young children with special needs in community based programs. Topics in Early Childhood Special Education, 18(2), 118-128.

Division of Early Childhood, Council for Exceptional Children. (DEC) (2007). Promoting positive outcomes for children with disabilities: Recommendations for curriculum, assessment, and program evaluation. Missoula, MT: Author.

Dunlap, G., Strain, P. S., Fox, L., Carta, J. J., Conroy, M., Smith, B. J., et al. (2006). Prevention and intervention with young children's challenging behavior: Perspectives regarding current knowledge. Behavioral Disorders, 32(1) 29-45.
Dunst, C. J., \& Dempsey, I. (2007). Family-professional partnerships and parenting competence, confidence, and enjoyment. International Journal of Disability, Development \& Education, 54(3), 305-318.

Filler, J., \& Xu, Y. (2006-2007). Including children with disabilities in early childhood education programs individualizing developmentally appropriate practices. Childhood Education, 83(2), 92-98.

Fox, L., Dunlap, G., Hemmeter, M. L., Joseph, G. E., \& Strain, P. S. (2003). The teaching pyramid: A model for supporting social competence and preventing challenging behavior in young children. Young Children, 58(4), 48-52.

Green, A. L., \& Stoneman, Z. (1989). Attitudes of mothers and fathers of nonhandicapped children. Journal of Early Intervention, 13, 292-304.

Gregory, S. P. (1996). Inclusive education for preschool children with disabilities. Support for Learning, 11(2), 77-82.

Grisham-Brown, J., Hemmeter, M. L., \& Pretti-Frontczak, K. (2005). Blended practices for teaching young children in inclusive settings. Baltimore: Brookes.

Harry, B., Kalyanpur, M., \& Day, M. (1999). Building cultural reciprocity with families: Case studies in special education. Baltimore, Maryland: Brookes.

Hemmeter, M. L., Ostrosky, M., \& Fox, L. (2006). Social and emotional foundations for early learning: A conceptual model for intervention. School Psychology Review. 35, 583-601.

Hohmann, M., \& Weikart, D. P. (2002). Educating young children: Active learning practices for preschool and child care programs (3rd ed.). Ypsilanti, MI: High Scope Press.

Individuals with Disabilities Education Act (IDEA) of 2004, PL 108-446, 20 U.S.C. s 1400 et seq.

Iruka, I. (2009). Ethnic variation in the association between family structures and practices on child outcomes at 36 months: Results from Early Headstart. Early Education and Development, 20(1), 148-173.

Janko, S., \& Swartz, I. (1997). Beyond microsystems: Unanticipated lessons about the meaning of inclusion. Topics in Early Childhood Education, 17, 286-307.

Lee, H., Ostrosky, M. M., Bennett, T., \& Fowler, S. A. (2003). Perspectives of early intervention professionals about culturally-appropriate practices. Journal of Early Intervention, 20, 281-295.

Lim, C., \& Able-Boone, H. (2005). Diversity competencies within early childhood teacher preparation: Innovative practices and future directions. Journal of Early Childhood Teacher Education. 26, 225-238.

Maschinot, B. (2008). The changing face of the United States: The influence of culture on early child development. Washington D.C.: Zero to Three National Center for Infants, Toddlers, and Families.

National Association of Education of Young Children (NAEYC). (2009). Developmentally appropriate practice in early childhood programs serving children from birth through age 8: Position statement. Retrieved June 20, 2009, from http://208.118.177.216/ about/positions/pdf/PSDAP.pdf

National Center for Children in Poverty. (2007). Low-income children in the United States: National and state trend data, 1996-2006. New York, NY: Author. Retrieved July 1, 2009, from http://www. nccp.org/ publications/pdf/text_761.pdf

National Clearinghouse for English Language Acquisition. (2007). What are the most common language groups for ELL students? Washington, DC: Author. Retrieved June 16, 2008, from http:// www.ncela.gwu. edu/expert/faq/05toplangs.html

National Professional Development Center on Inclusion. (2009). Why program quality matters for early childhood inclusion: Recommendations for professional development. Chapel Hill: The University of North Carolina, FPG Child Development Institute, Author.

Noonan, M. J., \& McCormick, L. (2006). Young children with disabilities in natural environments: Methods and procedures. Baltimore: Brookes.

Odom, S. L. (2000). Preschool inclusion: What we know and where we go from here. Topics in Early Childhood Special Education, 20(1), 20-27. 
Pretti-Frontczak, K., \& Bricker, D. (2004). An activity based approach to early intervention (3rd ed.). Baltimore: Brookes.

Pruitt, P., Wandry, D., \& Hollums, D. (1998). Listen to us! Parents speak out about their interactions with special educators. Preventing School Failure, 42(4), 161-166.

Rose, D., \& Meyer, A. (2002). Teaching every student in the digital age. Alexandria, VA: Association for Supervision and Curriculum Development.

Rose, D.H., Meyer, A., \& Hitchcock, C. (2005). The universally designed classroom: accessible curriculum and digital technologies. Cambridge, MA: Harvard Education Press. Retrieved April 3, 2009, from http://community.fpg.unc.edu/npdci

Sandall, S., Hemmeter, M. L., Smith, B. J., \& McLean, M. E. (2005). DEC recommended practices: A comprehensive guide for practical application in Early Intervention/Early Childhood Special Education. Longmont, CO: Sopris West.

Sandall, S. R, \& Swartz, I. S. (2008). Building blocks for teaching preschoolers with special needs. Baltimore, MD: Brookes.

Sandowski, M. (2006). Core Knowledge for PK-3 Teaching: Ten components of effective instruction. Foundation for Child Development Policy Brief, Advancing $P K-3,5$. New York: Foundation for Child Development.

Stahmer, A., \& Carter, C. (2005). An empirical examination of toddler development in inclusive childcare. Early Child Development and Care, 174(4) 321-333.

Stayton, V. D. (2003). Introduction to DEC personnel preparation recommended practices. In V. D. Stayton, P. S. Miller, \& L. A. Dinnebeil (Eds.), DEC personnel preparation in early childhood special education:
Implementing the DEC recommended practices (pp. 1-10). Longmont, CO: Sopris West.

Tsao, L., Odom, S., Buysse, V., Skinner, M., West, T., \& Vitztum-Komanecki, J. (2008). Social participation of children with disabilities in inclusive preschool programs: Program typology and ecological features. Exceptionality, 16, 125-140.

Turnbull, A., Turbull, R., Erwin, E. J., \& Soodak. (2005). Families, professional and exceptionality: Positive outcomes through partnership and trust (5th ed). Upper Saddle River, NJ: Pearson.

U.S. Department of Education, Office of Special Education Programs, Data Analysis System (DANS). (2008). OMB \#1820-0517, Children with Disabilities Receiving Special Education Under Part B of the Individuals with Disabilities Education Act, Implementation of FAPE Requirements, 2007. Data updated as of July 15, 2008. Retrieved from https:// www.ideadata.org/TABLES31ST/AR_2-1.htm

Wall, S., Taylor, N. E., Liebow, H., Sabatino, C. A., Mayer, L. M., Farber, M. Z., et al. (2005). Early Head Start and access to early intervention services: A qualitative investigation. Topics in Early Childhood Special Education 25(4) 218-231.

Xu, Y. (2007). Empowering culturally and linguistically diverse families of young children with disabilities: The double ABCX model. Early Childhood Education Journal, 34(6) 431-437.

$\mathrm{Xu}, \mathrm{Y}$. (2008). Developing meaningful IFSP outcomes through a familycentered approach using the double ABCX model. Young Exceptional Children, 12(1), 2-19.

\section{APPENDIX 1}

\section{IDENTIFYING FAMILY ROUTINES}

Describe your family (Who does your child interact with on a regular basis? List names and relationship to child).

\section{Describe your family's typical routines. (Name the things you do on a daily basis).}

Caregiver Routines (food related, dressing, bathing)

Pre-academic Routines (books, TV, computer, coloring, singing)

\section{Play Routines}

Community and Family Routines (chores, errands, outings)

How does your child participate in the various routines?

Tell me about the interactions you have with your child that are most enjoyable to you. 


\begin{tabular}{|c|c|c|c|c|c|c|c|c|c|c|c|c|c|c|}
\hline \multicolumn{15}{|c|}{ COLLABORATIVE PLANNING FOR EMBEDDED LEARNING } \\
\hline \multirow{2}{*}{$\begin{array}{l}\text { SAMPLE } \\
\\
\text { Goals \& } \\
\text { Objectives }\end{array}$} & \multicolumn{8}{|c|}{ School Routines } & \multicolumn{6}{|c|}{ Home Routines } \\
\hline & $\stackrel{\frac{\pi}{2}}{e^{2}}$ & 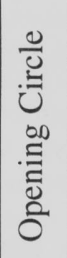 & $\begin{array}{l}\frac{\vec{a}}{a} \\
\frac{0}{0} \\
\stackrel{0}{0} \\
0\end{array}$ & 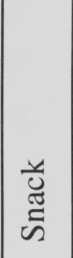 & 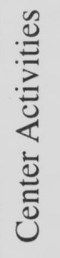 & $\begin{array}{l}\frac{a}{2} \\
\frac{0}{0} \\
\frac{0}{0} \\
0 \\
0 \\
0\end{array}$ & 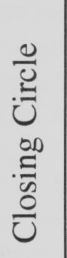 & 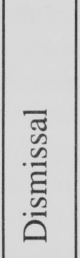 & 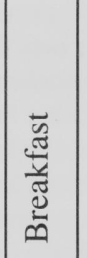 & 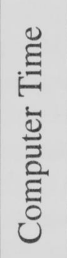 & 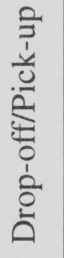 & $\stackrel{5}{0}$ & 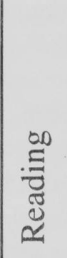 & 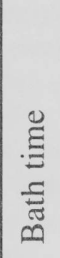 \\
\hline 1. Social Skill: Greets friends & $\mathrm{X}$ & & & & & & & $\mathrm{X}$ & & & $\mathrm{X}$ & & & \\
\hline $\begin{array}{l}\text { 2. Social: Initiates sharing } \\
\text { during cooperative activity }\end{array}$ & & & $\mathrm{X}$ & & & & & & & & & & & \\
\hline $\begin{array}{l}\text { 3. Social: Engages in } \\
2-3 \text { reciprocal exchanges. }\end{array}$ & & & & & & & & & & $\mathrm{X}$ & & & & \\
\hline $\begin{array}{l}\text { 4. Communication: } \\
\text { Uses two word phrases } \\
\text { to request desired items. }\end{array}$ & & & & & & & & & & $\mathrm{X}$ & & $\mathrm{X}$ & & \\
\hline $\begin{array}{l}\text { 5. Self-help \& Fine Motor: } \\
\text { Uses utensils to self-feed. }\end{array}$ & & & & $\mathrm{X}$ & & & & & $\mathrm{X}$ & & & $\mathrm{X}$ & & \\
\hline 怤 & 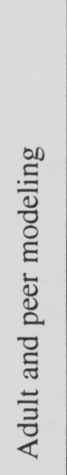 & & & 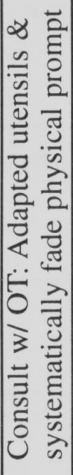 & & & & 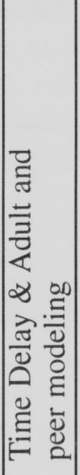 & 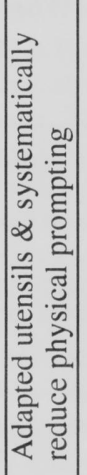 & & & 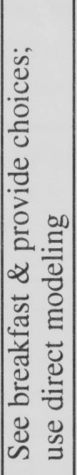 & & \\
\hline
\end{tabular}

